\title{
THE SNAKES AND LADDERS OF TWENTY-FIRST-CENTURY TRADE UNIONISM
}

\author{
COLIN CROUCH \\ European University Institute, Florence, and Max-Planck-Institut für Gesellschaftsforschung, \\ Cologne
}

Trade unions in the advanced countries face a difficult future. Their core membership bases in manufacturing industry and public services have become declining sectors of employment. Keynesian demand management, on which they depended for tight labour markets, has collapsed. Most industrial relations activity has shifted to the enterprise level, which they often find difficult to penetrate. Precarious employment, which makes union membership difficult, is growing. On the other hand, certain advantages offset these weak nesses. For a number of different recent economic and political élites often need the support of trade unions for national social pacts. Also, employment conditions continue to create new social problems for working people, which only unions can express. Unions in different countries encounter these combinations of fovourable and unfovourable prospects in very different ways, which is likely to produce increasing diversity among the emerging national patterns.

\section{INTRODUCTION}

As they enter the twenty-first century, trade unions throughout the industrial world seem to carry more problems than advantages. The following will certainly give full weight to these negative factors. However, a full account must also recognize certain positive elements in the situation facing unions at this point and, in particular, variations among countries in the balance of advantages and disadvantages. The idea of a game of snakes and ladders is useful here, with snakes representing problems that can lead to the weakening of trade unions, while ladders relate to the possibility of strengthening. As different union systems progress through the coming years, their liability to encounter snakes or ladders will depend, however, not on throws of a dice, but on certain structural predispositions and the capacity to take initiatives. True to the analogy, after a number ofyears the fates of different systems--primarily defined as 
national systems, though that requires frequent correction-are likely to have become very diverse.

We shall here consider first the 'snakes', the handicaps and difficulties, then the possible offsetting advantages.

\section{THE SNAKES AWAITING TWENTY- FIRST-CENTURY TRADE UNIONS}

\section{(i) The Decline of Trade Unionism's Core Membership Reserves}

Twentieth-century trade unionism came to have two great reserves of strength within the labourforce: its first historical base in the industrial manual working class, and its second, acquired during the second half of the century, in public-service employment at several levels.

Plotting the decline of these may be the best way in which to conceptualize the implications of globalization for unions. This phenomenon appears today in industrial relations largely as a crude means by which enterprises threaten to remove themselves to parts of the world with weak labour rights, or simply through a failure of industries in the advanced countries to compete on price terms with low-cost producers elsewhere. However, industrial and, indeed, many services enterprises are not in reality able to relocate around the globe as rapidly as they often pretend-partly because of the sunk costs of existing establishments, including both plant and labour skills, and partly because globalization brings new opportunities to the work-forces of the existing industrial countries as consumers in new areas of the world begin to be able to buy their products. Further, there are limits to the ranges of goods and services which can be produced by low-wage labour in locations with poor social infrastructure. But it is true that in order to retain and advance on existing advantages, the existing industrial countries are required constantly to reduce costs. They largely achieve this by improving productivity through both the increasingly efficient use of skilled labour and through the substitution of labour by machinery and technology. There is, therefore, a constant trend towards a decline in the unit labour needs of any given quantity of production.
This can often be achieved successfully, to the considerable advantage of the increasingly skilled labour which remains in those industries, and unions are important in the negotiations of the circumstances that make such changes possible. There is, however, a necessary decline in the numbers employed, which has three consequences. Most obviously it produces a decline in the overall strength of union membership; and while labour of all kinds is affected, it is primarily the core manual work-force in manufacturing which is reduced by the constant productivity rise-trade unionism's original and continuing heartland of recruitment. Second, if the relative loss of jobs in the exposed sectors is not compensated by job expansion elsewhere in the economy, there is a rise in the overall level of unemployment, which weakens unions, at least part of whose strength derives from conditions in the labour market. Finally, unions may come to represent secure labour-market insiders whose position is envied and resented by outsiders drifting between temporary work and unemployment, against whose interests unions then start to work.

These changes predate globalization as such, and belong to the general changes taking place in productive industry. For some time unions were protected from their implications by another development: as employment declined in productive industry, so it was growing in public services. The welfare state, or social and community services more generally, was the first main growth point in nonindustrial employment in the advanced countries (Crouch, 1999, ch. 4). Public employers being usually constrained to accept trade unions among their own employees, this became a highly organized sector. It has, however, been a recent victim of an ostensible consequence of globalization: pressure to reduce taxation levels, particularly on business and on price-sensitive activities, and, therefore, to reduce the size of public services. This kind of employment has, therefore, tended to peak, with either a reduction of the activities concerned or their privatization. In both cases there is a decline in unionism, private employers being both less constrained by the 'good industrial relations' model than governments (Freedland, 1998; Davies and Freedland in this issue), and, through their own fragmentation, less vulnerable to labour monopolies. In some cases privatization of the public sector has been more or 
less 'false'-existing large organizations are not likely to be broken up or radically to change their management pattern. These cases, which are quite widespread on the European continent, may not experience a weakening of unionism through privatization. As with manufacturing decline, the peaking of public-service employment is not solely the result of globalization. A politicization of tax rates for purely domestic electoral reasons began to make itself felt in some countries during the 1970 s. However, as with the decline in manual work, globalization has certainly reinforced the tendency.

With the partial exception of the Nordic countries, unions have been fairly unsuccessful in establishing themselves in private-sector services employment, which is now by far the most important area of job growth. This, therefore, becomes a particularly important source of both general weakness of and-because of the Nordic exception-diversity among national industrial relations systems.

\section{(ii) The Collapse of Keynesian Demand Management}

The collapse of Keynesian demand management has now become a universal phenomenon and threatens what had been the fundamental basis of post-war union strength: government commitment to maintaining full employment even in the face of inflationary labour markets. A strong case can be made for arguing that it was union abuse of this guarantee that eventually undermined it, though if the theorists of expectations-based economics have accurately modelled human behaviour, the 'abuse' was more widespread and extended into the mind sets of individuals, who took it for granted that government would act to protect employment even if this had been made uncompetitive by high wage costs. On the other hand, it should also be remembered that the model only came to be tested to destruction in the extraordinary politico-economic circumstances of the 1970s. The two oil shocks which, although by no means the only commodity price rises to impart an inflationary twist to the world's economies at that time, were at least in part politically motivated, and, therefore, exogenous to the Keynesian system. The virtually total rejection of demand management since that time is probably an overreaction, considerably encouraged by the fact that it is largely employer and capital interests which have gained from the more insecure labour markets which result from the downfall of the Keynesian model.

The implications of this change are too obvious to require detailed elucidation here. Not only do governments and central banks refuse to accommodate more than a small level of wage inflation, but the general onus of economic adjustment is thrown on to labour, which has to render itself competitive, particularly in the context of a growing globalization. From this stems the whole move to concession bargaining and a general realization that, except in certain particular occupations where there are labour-market shortages, the demand side of the labour market can usually dictate terms to the supply. Historically normal, this position had been reversed in many sectors by the underpinning of full employment on the Keynesian model.

This situation is probably less of a problem in those countries where the Keynesian guarantee was never strong. Germany, in particular, did not formally adopt Keynesian demand management until the late 1960 s, shortly before the model collapsed. Until then, and since, German unions always had to cope with a non-accommodating central bank (originally German, now European), which would punish inflationary pay rises with rises in interest rates, sometimes even in anticipation of, rather than in response to, wage increases in key industries considered likely to threaten price stability (Streeck, 1994). This fact, combined with acceptance of the importance of German exports (the driving force of the whole economy, and located in the union strongholds of engineering and chemicals) helped produce the legendary moderation and wage restraint of German collective bargaining.

Also relatively unaffected by the loss of Keynesianism are the southern European economies, some because they were under dictatorships during the heyday of Keynesianism; Italy because its political class seemed in the 1950s and early 1960 s to root economic management in special assistance for a few state and private monopolies, rather than in general demand management and employment maintenance. The problem has been felt most keenly in the UK, where Keynesianism was the leading if not sole instrument of economic policy, and in Scandinavia. 
(iii) The Shift to the Enterprise Level of Most Industrial Relations Activity

The shift to the enterprise level of most industrialrelations activity has been a particularly significant aspect of recent economic change. In the increased instability of the post-Keynesian economy, individual enterprises seek more autonomy in order to find their markets and make use of firm-level flexibility in order rapidly to adjust costs to the competitive conditions they encounter. At one level this leads them to seek freedom from governmentimposed costs, whether regulatory regimes or social security contributions. At another it leads them to resent constraints imposed by their own associations: the kind of generalizing role that these played in maintaining a level playing field within a national economy becomes less relevant within a globalizing economy with constantly shifting boundaries and no overall regulatory regime. Third, something still survives of the idea of individualized company cultures, which lead managements to seek again to evade external constraints, whether from government or their own associations. This demand peaked during the period of Japanese economic ascendancy in the 1980s (Aoki and Dore, 1994). It has moved into the shadows following the temporary demise of the Japanese case and the ascendancy of the very different model, of short-term, low-commitment employment contracts on both sides. However, this development in no way threatens the model of enterprise-level industrial relations.

Again, as with those changes associated with globalization, those limited to the shift to the enterprise did not start with the current employers' initiative. The origins were with the shop-floor-led militancy of the 1960s, seen especially in Italy and the United Kingdom, but also elsewhere. To some extent management's action has been a response to that prior challenge, obviously shifting the locus of action to their own structures rather than following the adhoc patterns generated by shop stewards and similar actors in the late 1960s.

More problematic, however, is the simple argument from many managements that, given the need for maximum flexibility of operations in current turbulent product markets, they simply cannot accept constraint from unions within their enterprises. This was, in fact, very frequently the stance of manage- ments in the earlier, post-war period. Particularly in continental Europe, there was a compromise whereby employers negotiated with unions at a general, usually national and sectoral, level, in exchange for unions not becoming involved within the work place. If employers no longer see the need for the national and sectoral levels, that leaves unions without a level of action which is acceptable to management. In particular, large firms may ostentatiously seek out (or threaten to seek out) production locations in countries where unions are subject to either state or managerial attack and marginalization; globalization again.

These changes are problematic for trade unions, since they imply a very management-determined model of employee relations, with the exception of limiting cases where management itself decides that an involvement of employees and/or their unions is part of its self-defined company culture. They do, however, have a differential effect. They are particularly severe for those unions which derive their strength from coordination at branch or national levels: in particular the Nordic, Austrian, Belgian, and Dutch national cases, and manual rather than non-manual workers in 'classic' Fordist industry everywhere. It should be less of a problem for cases such as the USA, or, in its very different way, Japan, where the priority of the enterprise level has long been the norm. Perhaps for this very reason, these are relatively weak systems of union influence, but at least these unions experience no new shocks. Similarly, for unions in the UK, particularly in the private sector, the move at least eases the previous tension between a strong local level and attempts at coordination. Relatively advantaged in a similarly ambiguous way are systems of generally weak union coordination capacity, such as France, Spain, or parts of Italy. In general, unions of non-manual and private-sector service employees are less troubled by these developments, since they have rarely been involved in detailed systems of coordination.

More ambiguous are the implications for German and Austrian unions, who have been accustomed to operating alongside a works council system. In Germany, unions are not formally part of this system, and during the 1950s and early 1960s they experienced this as a kind of weakness (Streeck, 1987). In particular, a whole series of issues which the unions might have taken up on behalf of mem- 
bers and thereby become very salient to them, were performed with statutory right by this non-union institution. However, they gradually learned how to work with works councils, incorporate them into their own structures and be of use to them. In principle, therefore, the new wave of enterpriselevel industrial relations finds them ready (Roth, 1992). In some cases this is working to unions' advantage, but in others managements are using a policy of establishing quality circles and similar consultative mechanisms to go over the heads of both the works councils and the unions.

Fairly comfortable with decentralization to the enterprise level, but in less ambivalent ways, are those union movements or industries which managed shifts to new patterns of 'co-ordinated decentralization' during the course of the 1990s (Traxler, 1995). The main examples have been Denmark (Due et al., 1994), the Netherlands (Visser and Hemerijck, 1997), and Ireland (Roche, 1999). They will be discussed in more detail in the context of union advantages (the 'ladders') below.

These relative advantages for management of a radical decentralization can be two-edged. As we know from the heyday of manual unionism, decentralized patterns of industrial relations are compatible with low inflation only when unions are weak, or at least very partial and limited in their points of strength (Crouch, 1993). Either general union weakness, or its strength only in privileged sectors of the labour market, therefore, seem to be a condition of the viability of this new model. The latter condition-privileged points of strength - can turn into a major disadvantage for unions if it permits their opponents to pit the interests of the underprivileged, the insecure, and the socially excluded against them - as already indicated in the earlier discussion above.

\section{(iv) The Collapse of the Standard Employment Model}

Although the majority of workers in all advanced countries work in what might be called standard employment-having a formal employment contract for what is commonly regarded as full-time work and without a fixed contract end-date-the number of persons working in other modes has grown rapidly (Standing, 1999). The new forms include both so-called precarious employment and a form of 'dependent self-employment'. Unionism has always been a movement of the employed in the sense of the standard 'dependent employee'. The decline of that status, therefore, presents problems. This generalization is not entirely true. Unions in some countries, particularly perhaps Italy, have had a record of organizing agricultural workers with all kinds of employment statuses and also (again in Italy) self-employed or even small-scale employer craftsmen (artigiani). For some occupations (for example, self-employed lorry drivers) there have been important examples in other countries too, including the UK. The real challenge comes where workers are not truly self-employed, in the sense of working for a number of clients, but work for a single so-called customer (really an employer) who requires them to have that status in order to avoid payment of social security contributions, adherence to employment law on such matters as health and safety and redundancy provisions, and union representation. In these cases self-employed status is imposed on the worker by the employer/customer precisely because this will disadvantage the former in industrial relations terms.

Similarly problematic for unions are forms of atypical work which either prevent employees from acquiring certain legal rights (e.g. temporary work) or leave them very vulnerable in the labour market. Established, especially skilled, employees becomea form of sunk cost, inhibiting the capacity of the employer to drop commitments to them and take advantage of capital's scope for mobility at the first sign of difficulty or disagreement over the terms of the labour contract. Tendencies away from the fixed-employment model are, therefore, part of the general shift towards increased mobility and avoidance of sunk costs characteristic of firms in a period of post-Keynesian product markets and globalization.

Sometimes part-time workers are part of the groups marginalized in this way, but this is not necessarily the case. Part-time work is often highly stable and seems to suit the mutual convenience of employers and employees (usually female) in a long-term way (Hakim, 1997). The problems it presents for trade unions even under these circumstances are that often (though by no means always) part-timers fall 
below thresholds (expressed in terms of weekly hours worked) for acquiring labour protection rights, and that the workers concerned sometimes do not feel sufficiently part of the labour-force to see union membership as relevant to their lives. These are not insuperable problems, but they have tended to restrict the recruitment of these workers-and, in several countries, therefore, of women.

More difficult than finding practical solutions to these problems is once again avoiding the trap into which unions might stumble as a result of them: the likelihood that unions will remain solely the representatives of an ever-declining number of workers in the old models of skilled export-oriented industry and/or secure public-service employment. It will often be far easier for an individual union or group of unions to remain within this fastness, ignoring what is going on in the rest of the work-force. Apart from gradually dwindling resources and influences, this has a further problematic implication: it leads unions to do little ornothing about the ranks of people working in the insecure parts of the labour marketoften working with an insecurity which is the obverse of the rights unions have won.

The difficulties created by labour-market atypicality and structural insecurity are severest where these phenomena have developed most, because they then become endemic within the labour market. Where false self-employment is concerned, the UK is a leading case; for temporary work, Spain; for the black economy, Italy and Spain. The problem is less important where flexibility has been achieved through less radical and disruptive means-for example, part-time working, as in other parts of the UK economy and more generally in the Netherlands; or where there has been a negotiated rather than managerially imposed flexibilization-again the Netherlands is the chief example (Visser and Hemerijck, 1997), to some extent also Denmark (Due et al., 1994).

\section{THE LADDERS: POTENTIAL PROPS TO CONTEMPORARY TRADE UNIONS}

Against these weighty disadvantages have to be set certain offsetting optimistic possibilities for twentyfirst-century trade unionism.

\section{(i) The New Need for Social Pacts}

In a number of countries governments and, less frequently, some employers' representative systems have a new requirement for widespread agreements among social partners. I call them new social pacts, because they are not simply continuations or even repetitions of earlier post-war situations, but respond to newly emerging exigencies-even if they sometimes build on legacies of trust and understanding established before. For this reason they are part of a future pattern and not just a look back to the past. These processes have several diverse causes, which merit separate discussion.

\section{European Monetary Union}

Elsewhere (Crouch, 2000) I have tried to argue in detail why I believe that European Monetary Union will strengthen national-level social pacts, for those countries whose currencies have merged into the euro. This might seem surprising for several reasons. First, surely this most Europeanizing of all projects ought to produce a European social pact, as several authors have indeed argued (Pochet, 1999; Traxler, 1999). Possibly in the very long term it will, but for the foreseeable future the central dynamic of the EU is that a Europeanizing (or rather globalizing) economy and European monetary system exist alongside nationally responsible politicians, trade unions, and employers' organizations. If monetary union removes some important mechanisms from these actors, particularly removing from governments the capacity to devalue the currency, these actors must be expected not simply to shrug their shoulders and accept that they have lost a capacity, but to look into their repertoire of policy resources and see what functional equivalents they have for the lost powers. In the case of devaluation, one such might be a capacity of social partners, with various kinds of incentive, to produce a wage restraint which would give the same result for external competitiveness as a devaluation. (Looked at differently, devaluation might, indeed, be seen as a means of reducing real wages in external markets in the event of a failure by social partners to achieve restraint.)

A second reason for surprise is that, the euro having started life, as it might have been expected to do, as a weak currency, no one is needing to provide mechanisms of this kind at the present time. Matters are working out in the opposite way to what one 
might expect in the event of the euro eventually becoming a strong currency. It is currently one of the countries which would have most difficulty articulating a social pact, France, which is experiencing particularly strong growth; and Germany which is in the currently unusual position of not requiring labour-market restraint to achieve a reduction in external relative wage costs, and which seems, partly as a result, to have lost capacity for pact-making. The interlude of euro-weakness has provided a valuable breathing space for countries such as France, Italy, and Spain, which had difficulty meeting the Maastricht criteria and would have increased difficulty securing reductions in realwage costs in the event of a euro moving upwards in relation to the dollar and sterling. In the longer term, as the euro eventually begins to behave this way, there will be a considerable test as to whether these countries have the capacity to replace currency movement with labour-market action.

A third reason for surprise at mentioning social pacts in the context of the euro is that this development comes as part of a general neo-liberal package which also includes deregulating the labour market and moving to enterprise levels of collective bargaining. Again, however, we must anticipate that moves to dislocate industrial relations actors both upwards (to an inaccessible European level) and downwards (to the enterprise level beyond political reach) will provoke a reaction from those actors limited to the nation-state level. Of course, in some cases the erosion of national and branch-level capacities to the enterprise may have gone so far that nothing could revive them. But this is something which will have happened differentially in different nation states, based, in any case, partly on their central capacities before the changes began. This will, therefore, be a source of considerable diversity within the euro zone. Those countries which are not part of European monetary union will have a different experience altogether.

Social pacts in the sense referred to here are broad technical agreements about levels of wage growth and also changes in employment practices which will be necessary to sustain external competitiveness, executed either at overall national level, or in certain key sectors which can then be expected to have influence on the rest of the economy. The words 'broad' and 'technical' are to be taken seriously. Agreements of this kind are unlikely to develop an extensive social and redistributive agenda as once did similar deals in the Scandinavian economies. Contemporary economies and indeed workforces are too internally diverse to permit of agreements of much precision. Existing examples, in for example Denmark, Finland, and Ireland, show that all that can be achieved is a very rough and ready set of overall guidelines, very unambitious in terms of social goals normally associated with trade unions, but at least preserving their role as actors in the system, which is our principal question here.

While broad, however, these deals are also technical. To be worth anything in terms of competitive edge, they have to secure relevant improvements in the external trading position, and they have to ensure some compatibility between goods and services open to export markets and those protected from such exposure. This is both a difficult technical and a daunting political task. Only those unions which have developed their own technical competenceprimarily the Nordic countries, the Netherlands, Austria, and Germany-will find themselves equipped for this role. Others may find they are acting as ciphers unless they can acquire such a competence.

As Hassel (1999) points out-reflecting perhaps on the sudden and surprising incapacity of German institutions to produce an effective social pact, or Bündnis für Arbeit-one fundamental criterion in all this is the will of government. If governments are both sufficiently powerful and tough-minded to be willing to threaten unilateral action in the absence of agreement on a pact, and sufficiently committed to consensus solutions, they might be successful in pressing the social partners to reach some useful agreements, as the Dutch case, in particular, shows. But, while not inherently contradictory, that combination of tough-mindedness and commitment to consensus is not easily found. Either side of it lie many examples of governments which lack either the capacity for the required degree of toughness (Germany?) or preference for social consensus (the UK?); both provide a difficult terrain for the development of social pacts.

\section{Welfare state reform}

In many countries unions have, in various different ways, a formal role in the administration of certain 
aspects of the welfare state, in particular mechanisms for the payment of pensions and unemployment and sickness benefit. The impact of this depends on certain very specific historical circumstances. For example, although French unions were excluded from national co-decision-making formost of the nineteenth and twentieth centuries, at a certain crucial moment, immediately after the Second World War, they were part of the national postNazi social compromise and, therefore, acquired a legally inscribed and thus virtually permanent role in the management of national pensions and social security funds. Italian unions acquired a similar right at the same time, which seemed equally exiguous during the long years of labour exclusion in Italy during the 1950 s and 1960 s, but which subsequently became a logical part of the rapprochement between the Italian state and organized labour.

There is an interesting contrast here with British labour, which in the early years (late nineteenth and early twentieth centuries) had been heavily involved in welfare administration. This stemmed from two causes (Finlayson, 1994). First, British trade unions had originated some of the earliest welfare benefits as a means of securing secondary benefits in their attempts to recruit members. It is a salutary reminder of the conditions of working-class life of that period that the most important benefit that a mutual fund could offer was the guarantee of a decent funeral at no expense to the widow. Second, early British welfare-state development in the early twentieth century was modelled on German precedents, which indicated a role in administration for trade unions. Initially, therefore, British labour was fully part of the continental European model of union involvement in the management of occupationally based welfare. However, during the 1920s this changed. As unemployment rose, unions found it increasingly difficult to manage their unemployment funds, and eventually relinquished control of them to the state. There was little controversy about this at the time; the growing ranks of socialists within the British labour movement in any case wanted a shift towards state funding of welfare. The issue then completely disappeared from political salience in the UK, and has never returned. However, an external observer might note the total absence of the unions from current debates in Britain over the reform of, in particular, the pension system, and might relate this to certain forgotten decisions made over 70 years ago.

This exclusion seems to be a genuine British peculiarity. In all continental European countries, unions have the kind of formal role in pensions and in sickness and unemployment insurance already discussed. In Scandinavia, they have a similar formal involvement in the state welfare system. In Japan and the USA they are very frequently involved in the running of enterprise-level pensions plans and use this as an important form of bargaining leverage. In at least the European cases, this involvement means that unions have to be courted to become part of a national consensus on welfare reform in general. This has two implications. It strengthens attempts by government and some employers to ensure that unions remain within a national consensus; and it slows down welfare reform, while ensuring that it takes forms acceptable to existing organized labour-though not necessarily to labour-market outsiders (Ebbinghaus and Hassel, 1999).

\section{The need for general consensus in the labour market}

Keynesianism and its associated politics of compromise between capital and labour, the granting of extensive labour rights, were not simply technical devices for ensuring smooth economic management. They also served a socio-political purpose. In the first half of the twentieth century and before, turbulence in the labour market lay behind some of the more general social upheavals of the period. It is possible to argue that the need for such measures has now passed. As we have seen, the main social bases of trade unionism have been eroding. Communism has disappeared from all the advanced countries. Fascism, the other disruptive twentieth century ideology, is showing clear signs of revival, but although that frequently uses labour movements, it is opposed to their autonomy and power. Alongside, and part of the arrival of 'the end of history', comes a final solution to the labour problem. A heterogeneous economy made up of very diverse and rarely solidaristic types of salaried and professional employees, a large number of persons with very marginal, insecure labour-market positions, and further large numbers pushed into a kind of selfemployment which does not give them any possibility of industrial relations in the old sense, have together achieved this. 
It is possible that this is the case; it is certainly the perspective offered by the americocentric perspective of contemporary economic science. It is, however, not surprising that many governments, political élites, and even employers feel less certain and hedge their bets. Similar things were being said up to the 1960 s concerning a final demise of the labour movement and of ideological conflict in general; then came the explosions of the late 1960s and early 1970 s. The relative decline of a social group, such as manufacturing workers, is no guarantee of their social passivity; rather the reverse. And it is doubtful whether, in the foreseeable future, any country of importance could envisage employment in manufacturing becoming as residual as, say, agricultural labour had by the late twentieth century. There are also limits to the industrial relations possibilities of the privatization of public services. Not only are some services very difficult to privatize, but frequently monopolistic conditions survive long into privatization, which can give organized labour similar opportunities as public employment as such.

Finally, the very fact that in some political contexts labour movements as cohesive, both economic and political forces, have been more or less broken, raises a problem in countries where individual unions as such are still lively. If, as is often the case, particularly in continental western Europe and Australasia, it is not politically feasible to conceive of actually breaking unions, there is a need for functional equivalents - which paradoxically can include the achievement of social pacts aimed at trading concessions from labour on such questions as forms of labour-market regulation, for continued participation by labour organizations in, and, therefore, influence over, the way in which such changes are carried out. The long-running and not entirely unsuccessful attempts of the French state to get some limited agreements among social partners and with itself provide an important example. On paper French unions are about the weakest in the advanced world; but they frequently demonstrate a continuing capacity to disrupt social order, which inhibits governments of varying colours and many employers from seeking their further marginalization.

\section{A more general concern for social stability}

The issues discussed in the previous sub-section, although they move into general political rather than industrial relations themes of social stability, remain concerned with the situation in the labour market itself. Trade unions, however, often feature in wider agenda of social order. Political authorities anxious about either overall order problems, or highly specific ones caused by such questions as political separatism, usually have an eye on the position of major trade unions. Unions almost everywhere remain not only the voluntary organizations with the most widespread connections to the general population outside the politico-economic élite, but also have a proven capacity for social mobilization and activism. If likely to ally themselves with problematic groups, they could be decisive in highly disruptive and separatist regional, ethnic, or religious conflicts. If encouraged to identify as part of the established apparatus of the united nation state, they will at best be neutralized as a potentially powerful part of a secessionist opposition, and at best become a force for positively reinforcing core identities.

This can be seen very strongly in Belgium, Italy, and Spain, given the regionally and culturally centrifugal forces within those countries. The attempts at social pacts to inhibit separatist conflicts are not always successful, but they certainly continue to be made. Something similar exists in Germany. Initially this resulted from the potentially fragile character of democracy in the post-war western republic. Today it is more concerned with coping with potentially disastrous divisions between the old western Länder and the still recently incorporated east.

Somewhat different but related is the situation in the infant democracies (or, more generally, infant capitalisms) in central and parts of eastern Europe. Here neither governments nor unions have much to offer each other. The former are busy implementing IMF requirements to deregulate labour markets and thereby reduce union power; the latter are very weak and stuck between inheriting an ostensibly important but politically treacherous continuity with the so-called unions of the communist past, or trying to find a role in the ideological no man's land that constitutes post-communist society. However, for those who have little, the offer of just a little more is often greatly appreciated. In this case the paradox is that they offer each other the same thing: legitimacy. Political classes only tenuously connected to their societies grasp at the chance of an embrace from a group of mass organizations, however slen- 
der these in turn may be. This is rather similar to, but more desperate than, the southern European cases. Unions in turn accept the ministerial hand-shake and invitation to top-level talks, even if these do nothing to stem the tide of actual policies hostile to their interests, because they at least take their place among the accepted institutions of polities and national establishments, the outlines and rules of inclusion and exclusion of which remain uncertain. Better to be at the receiving end of hostile policies but have a seat at the table than to take the same policies while being cast into the anxieties of social exclusion. Social pacts can be expected to thrive in this part of the world, and others with similarly slender institutional bases, such as much of Latin America and south-east Asia. These will initially be ritualistic, political pacts, usually lacking the detailed technical content of the earlier types discussed, though this may change as mutual trust as well as experience of how to operate these complex types of relationship grow.

In a rather different way, the European Union itself, or rather the European Commission, fits this pattern. It wants a legitimacy in its own right among the people of Europe, not just via national governments. Very rationally, therefore, it has developed a number of institutions: a strengthened European parliament; direct connections with regional and even local governments; and contacts with business lobbies and Europe-level social partner organizations. It does not have much to offer these last other than a seat at a consultative table, but this is often a desirable prize to the organizations, who otherwise have very little weight; in particular, Europe-level trade union organizations have difficulty persuading opposite-number employers' organizations to deal with them. So the Commission and the social partners, especially the unions, offer each other legitimacy, a scarce and desirable quality for both of them.

\section{(ii) The Emergence of New Work-related Social Problems}

A number of new social issues emerges in the context of the new post-industrial economy. These are in general not picked up well by current social policy. They relate largely to working time management in a two-gendered work-force, together with growing work stress, which may well involve either member of a dual-earning partnership in such a way that the partner is unable to help, being absorbed in his/her own problems. Far from resolving the general, public social questions raised by employment in the work-force, the post-industrial economy seems to increase these. This occurs mainly through its invasion of the earlier gender division of labour which somehow enabled (or required) women to reserve a certain area of life outside the occupational sphere and, therefore, as a form of 'recuperation' for those engaged in it (Crouch, 1999, chs 2, 7, 15). This becomes less and less possible, raising the issue of how men and women are to secure some relief from their role in the occupational system and cope with the stress it causes in their lives.

While this is clearly a question sociale, as the general role of the working class was identified in late nineteenth-century France, and, therefore, one to which unions are in principle relevant, it is by no means obvious that they can help much with it. They are accustomed to dealing with occupational issues alone, and in many countries have been particularly responsive to male workers only. However, this remains a potential field for them, and few other social institutions seem capable of tackling it. The issue is most likely to be seized to good advantage where unions have already recruited large numbers of women, since they can be expected, more than men, to want to place issues of this kind on a political agenda. So far the Nordic unions have developed most expertise here, having a particularly good membership base among women workers. Publicservice unions in many countries usually have a majority of women among their members and are particularly well placed to take advantage of change. Some British and North American unions have also been quick to adapt both to recruiting female members and to responding to their special interests. Less well placed are those individual unions and national movements still relating heavily to the male manual manufacturing model-for example Germany and Italy.

\section{COUNTRY PROFILES}

It is now possible to run different trade-union systems through this basic framework of snakes and ladders. This can be done at a number of levels. Particularly interesting would be to consider a number of individual unions, taking into account their past 
records of behaviour and making predictions concerning their chances of future survival and success. Here, however, I must limit myself to a small number of contrasts between so-called national systems, bearing in mind, however, that such generalized systems do not necessarily account for all unions within their borders. The extent to which there are national systems of industrial relations will become increasingly problematic as the globalization and denationalization of nation-state-based systems proceeds. To some extent, therefore, one is here dealing with fading stereotypes.

\section{(i) The United Kingdom}

British unions face a very distinctive and sometimes surprising path. They are only moderately affected by the snake of the decline of manufacturing and public service. The decline of manufacturing has long been anticipated in the UK, and British unions have been relatively successful in establishing bases in banking and other core sectors of private services. They have also managed to sustain membership in parts of the public service as this was privatized. However, like most other union movements, they remain relatively weak among the private-service growth points of the twenty-firstcentury economy.

The shift of collective bargaining to the enterprise or plant level also has fewer implications for British than for many other unions, since they were rarely able to transcend this level during the period when most advantages seemed to lie with centralized unions capable of national coordination. In an important if ambiguous sense, British labour was already active at this level when management decided to arrive there. The ambiguity is partly that management does not necessarily choose the levels of action preferred by shop-floor union activists. These latter wanted to concentrate bargaining at whatever work-group level they found it easiest to organize; management wishes to concentrate at the level of its manageable cost centres. These will only coincidentally be the same.

In contrast, the decline of the standard employment model has affected British unions very severely, though again with ambiguities. British unions have had less need than many to cope with the strong division between permanent insiders and marginalized outsiders. British labour rights having become generally weak during the $1980 \mathrm{~s}$, the contrast between those with rights and those without is not so great as in, say, Spain. For similar reasons, British employers have had less recourse than many others to concepts of temporary and black employment. They have, however, made much use of 'false' selfemployment, which has given unions considerable difficulties. Also important within the UK economy has been the major role of part-time female work. Here, however, there are many examples of important initiatives and new ideas among British unions, which have been more advanced than most in promoting issues of particular interest to women, especially part-timers. They are helped by the fact that most British part-time work is really 'standard' employment, in the sense of being based on normal employment contracts; it is just that the hours worked are fewer.

The decline of the standard Keynesian employment form has been very difficult for British unions, since Keynes's own country had depended particularly heavily on straightforward demand management for 'taming' the market economy. There were far fewer of the special relationships between banks and enterprises that were important in the German or Italian post-war economies or, in their very different ways, between state and major enterprises as in France or Sweden or, via the all-important science-based armaments sector, the USA. While many of these social support mechanisms for the economy - with the exception of the armaments model-came under pressure, principally from the USA, for reform and dismantling as protectionist during the 1990 s, the virtually pure Keynesian system of the UK was forced to change considerably earlier. This was a fundamental blow for many of the expectations of British unions.

The mixed position of British unions in relation to the snakes awaiting twenty-first-century trade unionism is similarly matched by the ladders. There is virtually nothing available for British unions in terms of social pacts; not one of the possibilities for these signalled above is relevant. The country remains outside the euro; as noted above, British unions opted out of management of the welfare state during the $1920 \mathrm{~s}$; since the defeat of the disastrous coalmining strike in 1985, British labourhas been unable to pose a challenge to social order. The country 
certainly has general problems of national coherence, particularly but not solely relating to Northern Ireland; but organized labour has not managed to make itself seem important to these.

On the other hand, and as already indicated above, British unions have shown considerable capacity to respond to changes in the labour market, in particular the recruitment of women-and also ethnic minorities - and are, therefore, in a good position to respond to some of the newly emerging employment-related issues.

Overall, British unions emerge from the snakes and ladders of future challenges as adaptable, willing and able to change and move to where opportunities exist, but confronting a very inhospitable politicoeconomic context. They seem likely to remain worthy under-labourers in non-strategic areas of economic life.

\section{(ii) The Federal Republic of Germany}

The position of German unions is rather different. They are even more unable than the British to cope with the decline of core sectors, especially manufacturing, since manufacturing industry has remained strong and competitive for far longer in this economy and, therefore, the challenge to move beyond it has been less pressing until very recent years. On the otherhand German unions-like British ones though in totally different ways - have, as noted, been prepared for the move to the enterprise level through their complex relations to the works council system. However, as we have already noted, employers are not always allowing them to reap that advantage; like British unions, they experience problems in that managements often seek a different basis for enterprise-level personnel policies from that embodied in the works council system. On the other hand, they have, indirectly, a presence at this level which they can and do use to anticipate change.

So far, the decline of standard employment has affected the German economy considerably less than the British. There is less false self-employment and less part-time work. The two economies are similar in not having much scope for temporary employment. This is a form of relative strength of German unions. On the other hand, it is something they achieve at the expense of falling into the trap, identified several times above, of coming to represent an ostensibly privileged group of labour-market insiders to the possible cost of various kinds of outsiders. Outsiders here mainly comprise women and ethnic minorities and, to some extent, East Germans. It does not, however, include the young, usually to be counted among the excluded: the vocational education system continues to make Germany one of very few countries in the world where youth unemployment is below that of adults (Crouch et al., 1999, ch. 2).

German unemployment, like that of many European countries but unlike that of the UK, is more female than male. German women, it seems, want to work but cannot find jobs. Given a welfare state primarily based on transfer payments rather than the provision of services, and an economy based overall on (male) manufacturing rather than (relatively female) services, this situation is likely to continue. Immigrants could be of real help here, even if in rather unattractive ways. They tend disproportionately (in contemporary European terms) to comprise males of working age. Provided they have useful skills and are admitted legally and therefore pay taxes rather than comprise part of the black economy, immigrants are likely to be a contributing rather than a recipient element of a European welfare state-an important issue in Germany and many other parts of continental Europe with aging populations. They are also likely, given the relative expectations given them by their life experience, to be willing to work for longer hours and with less favourable working conditions than their native European counterparts. Rather than being a threat to European employment and welfare states, which is how they are normally seen, immigrants can actually be its salvation. This was true of the earliest waves of immigrants into post-war West Germany: ethnic Germans expelled from eastern and central Europe. It was also true of the Italian, Turkish, and other workers who moved into Germany after the economy achieved full employment in the late $1950 \mathrm{~s}$. It has not, however, been true of changes following East German unification. East Germans after 1989 had expectations of immediately experiencing the prosperous life style of the Federal Republic. Immigrants from further east came with fewer expectations; but they, like many of their counterparts in 
other west European countries, face the problem of being seen as negative factors in the employment equation rather than the positive ones which they really are.

The situation which today confronts the renewal and advancement of industrial relations and a strategic role for unions in Germany is, therefore, very different from in the past. It relates primarily to developing the post-industrial parts of the economy and confronting gender and ethnic issues. This is why, although on all other grounds one would expect German unions to take more advantage of the ladders than of the snakes confronting them, this is somehow not the case. Every incentive to socialpact formation lies open to them. In the long run the country will have every need of the wage-restraint and efficiency-improving dynamic imposed by European monetary union. The unions are fundamental to the operation of the welfare state, especially the pensions and income compensation schemes, which are in need of reform. The history of the Federal Republic also inclines it considerably to concertative solutions. Further, while sharing with their counterparts in the Nordic countries a high level of technocratic competence for participation in pacts with a serious technical content, Germany also has a considerable share in the almost opposite form of incentive imparted by anxieties concerning national integration. The nightmare of the earlytwentieth-century German past still lingered, with German policy-makers worried about social order when unification arrived after 1989 , bringing a major issue of regional integration. In fact, granted the size of the challenge, unification has proceeded remarkably successfully; but it remains a social-order concern. Given these incentives it is surprising, and reflects the weight of the difficulties of the transition to post-industrialism mentioned above, that the attempt to achieve a social pact, the so-called Bündnis für Arbeit, has met with such little success.

\section{(iii) The Netherlands}

A very different picture is now presented by Dutch industrial relations, which only a few years ago seemed more hopelessly incapable of change than Germany today (Visser and Hemerijck, 1997). Trade unions had slid down virtually all the snakes. Union membership was in deep decline. The economy, rather like the British, was de-industrializing rapidly; this had negative consequences for industrial employment, while governments were trying to reduce public spending and, therefore, public employment. The unions remained weak in the private services sector, and membership levels were declining very sharply indeed. They had also never managed to make the same success as their German counterparts of the admittedly newer works council system. They remained very heavily dependent on the atrophied centralized collective bargaining system and were, therefore, unable to take advantage of the shift of industrial relations to the enterprise.

Oddly the situation was rescued by means of a snake which became a kind of ladder: atypical work, in particular part-time employment. Following a period of experimentation with pure neo-liberal models in the early $1980 \mathrm{~s}$, Dutch employers gradually came to see future potential in the old consensus Dutch model. Its strong institutional legacy could be adapted to new purposes. This was the ladder of the social pact. Although the institutions that embodied that system had seemed to be empty shells, embodying religious and class conflicts of a bygone age (Hemerijck, 1992), they also embodied real organizational resources and possibilities of coordination. These enabled Dutch social actors to take advantage of possibilities for collective action denied to their colleagues in other societies. New life was breathed into the old model as it was used to negotiate a series of labour-market changes which elsewhere were either imposed from above by management on a defeated work-force (e.g. the UK), or resisted successfully by trade unions (as in Germany). In the Netherlands, unions were by no means strong enough to take up such a strong resistance as their German colleagues have; but neither could they be totally defeated, as in the British case, because it was impossible to inflict that kind of exclusion on a major social group in Dutch society. They needed to treat, and they needed to be treated with.

From this emerged the very distinctive Dutch social compromise of the late 1990s: a kind of supervised deregulation of the labour market, leading in particular to a major extension of part-time work. This includes men as well as women, though of course the latter predominate. Partly for this reason, the level of female employment participation in the 
Netherlands, once by far the lowest in northern Europe, has risen rapidly.

Does the new Dutch model mean the implementation of a British employment model, but with a weak union movement bludgeoned into accepting it within social pact structures? Or is it more like the German model, making use of bipartite and tripartite institutions to regulate a deregulation, but with a capacity for flexibility enforced by both greater union weakness and, paradoxically, a weaker manufacturing industry? This perhaps remains the most significant debating point for Europe's trade unions as they enter the twenty-first century.

\section{REFERENCES}

Aoki, M., and Dore, R. (1994), The Japanese Firm, Oxford, Clarendon Press.

Crouch, C. (1993), Industrial Relations and European State Traditions, Oxford, Clarendon Press.

- (1999), Social Change in Western Europe, Oxford, Oxford University Press.

- (2000), 'National Wage Determination and European Monetary Union', in C. Crouch (ed.), After the Euro: Shaping Institutions for Governance in the Wake of European Monetary Union, Oxford, Oxford University Press.

- Finegold, D., and Sako, M.(1999), Are Skillsthe Answer? The Political Economy of Skill Creation in Advanced Industrial Countries, Oxford, Oxford University Press.

Due, J., Madsen, J. S., Jensen, C. S., and Petersen, L. K. (1994), The Survival of the Danish Model, Copenhagen, DJøF. Ebbinghaus, B., and Hassel, A.(1999), 'The Role of Tripartite Concertation in the Reform of the Welfare State', Transfer, $1-2,64-81$.

Finlayson, G. (1994), Citizen, State, and Social Welfare in Britain 1830-1990, Oxford, Clarendon Press.

Freedland, M.(1998), 'Law, Public Services, and Citizenship-New Domains, New Regimes?', in M. Freedland and S. Sciarra (eds.), Public Services and Citizenship in European Law: Public and Labour Law Perspectives, Oxford, Clarendon Press.

Hakim, K. (1997), 'A Sociological Perspective on Part-time Work', in H.-P. Blossfeld and K. Hakim, (eds), Between Equalization and Marginalization: Women Working Part-time in Europe and the United States of America, Oxford, Clarendon Press.

Hassel, A. (1999), 'Bündnisse für Arbeit: Nationale Handlungsfähigkeit imeuropäischen Regimewettbewerb', MPIfG Discussion Paper 99/5, Cologne: Max-Planck-Institut für Gesellschaftsforschung.

Hemerijck, A. (1992), 'The Historical Contingencies of Dutch Corporatism', D.Phil. thesis, University of Oxford.

Pochet, P. (1999), 'Monetary Union and Collective Bargaining in Belgium', in P. Pochet (ed.), Monetary Union and Collective Bargaining in Europe, Brussels, Peter Lang.

Roche, W. K. (1999), 'The End of New Industrial Relations?' Working Paper SPS 99/8, Florence, European University Institute.

Roth, S. (1992), 'Japanization, or Going Our Own Way?' in Hans-Böckler Stiftung, Japanization, or Going Our Own Way?, Düsseldorf, Hans-Böckler Stiftung.

Standing, G. (1999), Global Labour Flexibility, Basingstoke, Macmillan.

Streeck, W. (1987), 'Industrial Relations and Industrial Change: The Restructuring of the World Automobile Industry in the 1970s', Economic and Industrial Democracy, 8, 437-62.

- (1994) 'Pay Restraint Without Incomes Policy: Institutionalized Monetarism and Industrial Unionism in Germany', in R. Dore, R. Boyer, and Z. Mars, (eds), The Return to Incomes Policy, London, Pinter.

Traxler, F. (1995), 'Farewell to LabourMarket Associations? Organized versus Disorganized Decentralization as a Map for Industrial Relations', in C. Crouch and F. Traxler (eds), Organized Industrial Relations in Europe: What Future?, Aldershot, Avebury.

- (1999), 'Wage-setting Institutions and European Monetary Union', in G. Huemer, M. Mesch, and F. Traxler (eds), The Role of Employer Associations and Labour Unions in the EMU, Aldershot, Ashgate.

Visser, J., and Hemerijck, A. (1997), A Dutch 'Miracle', Amsterdam, Amsterdam University Press. 